\title{
EVALUASI FORMATIF PADA VIDEO PEMBELAJARAN MAJOE DJAYA PRODUKSI EDUARTION
}

\author{
Erika Oktarini, Abdul Gafur \\ Matrik Ladang Belajar, Universitas Negeri Yogyakarta \\ o_akire@yahoo.com, agafur68@gmail.com
}

\begin{abstract}
Abstrak
Tujuan dari evaluasi formatif ini adalah untuk menentukan validitas dari pilot project Video Majoe Djaya dalam aspek instruksional dan media. Selayaknya sebuah evaluasi formatif, hasil lain yang diharapkan adalah daftar revisi untuk diajukan kepada para pembuat keputusan dalam memperbaiki dan meningkatkan seri video ini. Studi menggunakan Model Evaluasi Formatif Ogle yang untuk mengevaluasi tiga dari seri video, berjudul Bilangan Bulat, Badar dan Barung I, dan Logaritma. Masing-masing video secara berurutan diperuntukan bagi siswa kelas 4, 7, dan 10. Prosedur evaluasi melibatkan review dari ahli, sesi one-to one, small group, dan field test bagi pengguna, serta review dari guru. Hasil dari penentuan validitas dalam aspek instruksional adalah baik, ditunjukkan dari modusnya yang bernilai 4. Sedangkan dari aspek media, kualitas video adalah baik, ditunjukkan dari modusnya bernilai 4 dari 5. Video juga dapat meningkatkan outcome pembelajaran sebesar $44.36 \%$ seperti yang ditunjukkan oleh hasil rerata gain score. Seri video ini dapat untuk digunakan setelah dilakukan revisi. Revisi penting yang perlu dilakukan dalam pengembangan video fase kedua adalah: 1) membagi video ke dalam bagian-bagian yang lebih pendek berisi sub bab dari materi, 2) menyediakan penjelasan yang berisi tujuan dari video untuk mengatasi kesalahpahaman dalam penggunaan video, 3) menyediakan penjelasan bagaimana menggunakan video bagi siswa maupun bagi guru, 4) menuliskan standar kompetensi ke dalam video untuk meningkatkan kejelasan bagi siswa dan guru, dan 5) memperbarui strategi instruksional supaya sesuai dan seimbang antara unsur ketepatan dan hiburan.
\end{abstract}

Kata kunci: Video Pembelajaran, Evaluasi Formatif

\section{FORMATIVE EVALUATION ON MAJOE DJAYA INSTRUCTIONAL VIDEO PRODUCED BY EDUARTION}

\begin{abstract}
The objective of this formative evaluation is to determine the validity of Majoe Djaya Video pilot project in the instructional and media aspects. As a formative evaluation, another expected result is a list of revision to be proposed to the decision-makers in revising and improving of this video series. This study uses Ogle formative evaluation method to evaluate three of the video series: Bilangan Bulat, Badar and Barung I and Logaritma. Each video is respectively aimed for target users in grades 4, 7, and 10. The evaluation procedures involve expert review, one-to-one user session, small-group user session, field test for the users, and teacher review. There are three instructional media experts and three subject matter experts reviewing the videos. The data collection involved 150 students from SD Jetisharjo, SMP 6, and SMA 9 Yogyakarta in November-December 2012. The result of the validity determination of Majoe Djaya Video is considered good in both instructional and media aspects, as shown by its mode that is 4 out of 5(using Likert Scale). The use of the video resulted in learning improvement as much as $44.36 \%$, gained from the gain score mean. This video series is feasible for utilization after being revised. The essential revisions for further development of the video are: 1) dividing the video into smaller sections containing subchapters of the materials, 2) providing an explanation containing the purpose of the video to overcome misunderstanding of the video utilization, 3) providing explanations of how to use the video, not only for the users but also for the teachers, 4) providing competency standards written on the video (as video captions) to improve material clarity for users and teachers, and 5) renewing the instructional strategy so that the element of accuracy and entertainment can be appropriate and balanced.
\end{abstract}

Keywords: Instructional Video, Formative Evaluation 


\section{Pendahuluan}

Pada tahun 2010, Eduartion dengan disponsori oleh Kedutaan Belanda memproduksi pilot projek video pembelajaran matematika Majoe Djaya. Eduartion adalah studio yang mendedikasikan karyakaryanya pada sumber pembelajaran gratis, menyenangkan, dan sistematis. Pengembang ini memperkenalkan beberapa fitur khusus di dalam video tersebut, seperti: lukisan mind map, lagu rumus, cerita humor, dan lembar kerja SOSIS. Sebelumnya video ini telah diputar di beberapa sekolah di Jogja selama 2011, yaitu SMA 1, SMA 3, SMA 9, SMA 6, SMA Muhammadiyah 1, SMP 6, dan SD Jetis Harjo. Proses pemutaran diatur oleh sekolah dan menggunakan ruang kelas atau ruang audio visual. Selama pemutaran, para siswa berpartisipasi dalam langkah demi langkah menyelesaikan soal yang ada dalam video menggunakan lembar kerja SOSIS. Pada akhir sesi, kemudian siswa menuliskan pendapat mereka secara bebas mengenai video. Dengan menggunakan kuis sederhana yang terdiri dari dua pertanyaan terbuka, siswa memberikan opini mereka mengenai pemahaman dan ketertarikan mereka. Data yang dikumpulkan melibatkan 2500 siswa dan secara sederhana ditarik kesimpulan menghasilkan $90 \%$ siswa memberikan umpan balik yang positif. Namun demikian, secara akademis, Belum terdapat data yang valid. Evaluasi video ini memerlukan prosedur yang lebih sistematik dan ilmiah. Walaupun terdapat banyak model dan pendekatan evaluasi, namun sangat sedikit dalam hal ini yang membahas secara spesifik mengenai evaluasi formatif (Ogle, 2002).

Menurut AECT, setiap media yang terdapat di pasaran atau publik perlu dievaluasi untuk menentukan validitas isi maupun medianya. Salah satu cara penting untuk membedakan evaluasi adalah dengan mengklasifikasikannya menurut objek yang dievaluasi, yang biasanya berupa program, proyek, dan produk (materi). The Joint Committee on Standards for Educa-tional Evaluation (1981) menyediakan definisi untuk setiap tipe evaluasi. Secara khusus pengertian dari evaluasi materi atau produk media pembelajaran adalah evaluasi yang menilai asses the merit or worth of content-related physical items, termasuk buku, panduan kurikulum, film, tape, dan semua materi pembelajaran. Penilaian bukan dilakukan untuk mengadakan pembelaan selama proyek berlangsung. Namun tujuannya adalah untuk merencanakan program dengan lebih baik. Menurut Weiss (1972, p.4), tujuan dari penelitian evaluasi adalah untuk mengukur efek dari program dibandingkan dengan tujuan yang ingin dicapai sehingga dapat menjadi masukan bagi para pengambil keputusan dalam memperbaiki pengembangan pro-duk lebih lanjut. Evaluasi formatif adalah salah satu sub domain dalam definisi teknologi pembelajaran. Seels (1994) menyebutkan bahwa evaluasi formatif adalah proses mengumpulkan informasi yang cukup dan menggunakan informasi ini sebagai basis bagi pengembagan lebih lanjutan dari objek yang dievaluasi.

Menurut Flaggs (1990), terdapat beberapa alasan kenapa evaluasi formatif kadang tidak dilakukan pada pengembangan materi pendidikan khususnya yang berkenaan dengan teknologi elektronik. Beberapa alasan yang sering ditemukan adalah persoalan waktu, uang, sifat alami manusia, harapan yang tidak sesuai, kesulitan pengukuran, dan kekurangan pengetahuan. Evaluasi adalah salah satu langkah penting dalam proses desain dan tetap saja sering terlupakan. Banyak proyek pembelajaran yang tidak pernah dievaluasi oleh ahli maupun pengguna sebelum digunakan. Permasalahannya adalah terkadang perancang "terlalu dekat" dengan proyek tersebut sehingga kehilangan kemampuan untuk mengevaluasi keefektifan dari produk yang dikerjakan. Melibatkan orang luar untuk menilai proyek adalah hal yang penting menurut Flaggs. Hal ini akan membantu menentukan apakah produk benar-benar telah sesuai dengan tujuan atau jika mungkin terdapat penyesuaian kecil maupun besar 
yang perlu dilakukan supaya pembelajaran mencapai kapasitas maksimalnya.

\section{Metode Penelitian}

Evaluasi formatif yang digunakan dalam penelitian ini adalah studi deskripstif dari produk pembelajaran baru yang dikembangkan. Tahapan evaluasi dilakukan menurut model formasi evaluasi Ogle (2002) dengan penyesuaian pada beberapa bagian. Model ini menggunakan langkah-langkah yang telah diidentifikasi sebelumnya oleh Tessmer mengenai evaluasi formatif secara umum dan TenBrink untuk model evaluasi yang baik (Ogle, 2002, p.57). Menurut Ogle terdapat langkah-langkah yang dapat disaring dari proses evaluasi formatif menjadi lebih komprehensif dan manageable. Langkahlangkah yang telah disaring dari berbagai sumber itu kemudian menghasilkan sebuah alat yang disebut Evaluation Express, berupa lembar kerja yang dapat membantu para perancang instruksional, pengembang, dan evaluator dalam merencanakan evaluasi formatif. Penyesuaian yang perlu dilakukan belum termasuk dalam langkahlangkah revisi instruksi dan mempublikasikan hasil. Penyesuaian yang diambil dimaksudkan untuk mensinkronkan langkah-langkah dan tujuan dari evaluasi formatif. Pada tahap ini, video Majoe Djaya sedang berada pada pengembangan fase satu atau pilot dimana revisi belum dimungkinkan. Evaluasi formatif yang dilakukan pada tahap ini adalah dimaksudkan yang pertama untuk mengukur validitas instruksional dan media. Yang kedua, evaluasi ini ditujukan untuk memperoleh daftar revisi yang akan digunakan dalam fase kedua dari pengembangan produk. Penelitian ini perlu diklarifikasikan sebagai penelitian evaluasi bukan penelitian pengembangan.

Berikut ini adalah langkah-langkah yang telah dilakukan menggunakan Evaluation Express Tool dalam evaluasi formatif ini: (1) klarifikasi tujuan dari produk; (2) mendefinisikan tujuan evaluasi, termasuk klarifikasi tipe evaluasi; (3) penentuan per- tanyaan evaluasi; (4) perencanaan evaluasi; (5) menentukan kriteria, indikator, dan sumber data; (6) pengembangan instrumen; (7) mengajukan proposal evaluasi; (8) revisi proposal evaluasi; 9) menjadwalkan pertemuan evaluasi; (10) melakukan evaluasi; (11) melaporkan hasil. Tujuan dari seri Video Majoe Djaya adalah untuk menyediakan sumber latihan bagi siswa dengan menggantikan salah satu peran guru, yaitu peran menjelaskan cara menyelesaikan soal. Seri video ini ditunjukan untuk memberikan waktu yang lebih longgar bagi guru untuk melakukan peran-peran strategis di kelas, yaitu sebagai fasilitator dalam proses penemuan konsep. Pengembang percaya hal ini dapat terjadi jika ada sebuah seri video yang dapat menggantikan peran guru dalam melakukan penjelasan berulang dalam teknis mengerjakan soal-soal yang sifatnya kemudian menjadi tugas mekanis setelah dilakukan berulangulang setiap tahun.

Tipe evaluasi formatif dalam penelitian adalah untuk pengambilan keputusan dan perbaikan produk. Dengan demikian, evaluasi ini harus mampu menentukan validitas produk, outcome pembelajaran yang dapat dicapai, dan juga daftar revisi untuk meningkatkan keefektifannya. Adapun pertanyaan evaluasi yang perlu dijawab adalah: 1) sejauh mana validitas instruksional dari video pembelajaran matematika Majoe Djaya? 2) sejauh mana validitas media dari video pembelajaran matematika Majoe Djaya. Pertanyaan-pertanyaan ini lebih jauh dikembangkan ke dalam detail yang perlu diukur seperti dalam aspek validitas instruksional mengenai keakuratan, kebermanfaatan, kejelasan, strategi instruksional, dan efektivitas keluaran kognitif. Sementara dalam aspek validitas media, terdapat beberapa aspek yang perlu diukur yaitu karakterisitik desain secara umum, kualitas audio dan video, kecukupan material suplemen, dan reusability.

Dalam rencana evaluasi juga termasuk penentuan prosedur. Prosedur yang dilibatkan dalam evaluasi formatif ini adalah 1) review ahli; 2) one-to-one; 3) small 
group; dan 4) field test. Ahli yang dilibatkan adalah tiga orang ahli konten (SME) dan tiga orang ahli media pembelajaran (IME). Sementara siswa yang dilibatkan berasal dari SD Jetis Harjo, SMP 6 Yogyakarta, dan SMA 9 Yogyakarta. Pada ta-hap one-to-one, tiga orang siswa mengikuti sesi secara terpisah. Small group melibatkan 5-8 siswa dan field test melibatkan 30-35 siswa untuk masing-masing sekolah. Dalam hal ini guru juga dilibatkan untuk memberikan data pendukung dalam aspek feasibility. Pengambilan data dilakukan selama bulan November-Desember 2012.

Kisi-kisi instrumen seperti pada Tabel 1 menunjukan bahwa variabel instruksional dibagi menjadi dua sub variabel, yaitu konten dan desain. Sementara variabel media dibagi menjadi ke dalam sub variabel teknis produksi dan fitur khusus. Masing-masing subvariabel ini kemudian didetailkan dalam aspek-aspek yang merujuk kepada Beaudin (1993), Dick and Carey (2009), Smaldino (2008), dan Gagne (1992).
Kisi-kisi Instrumen

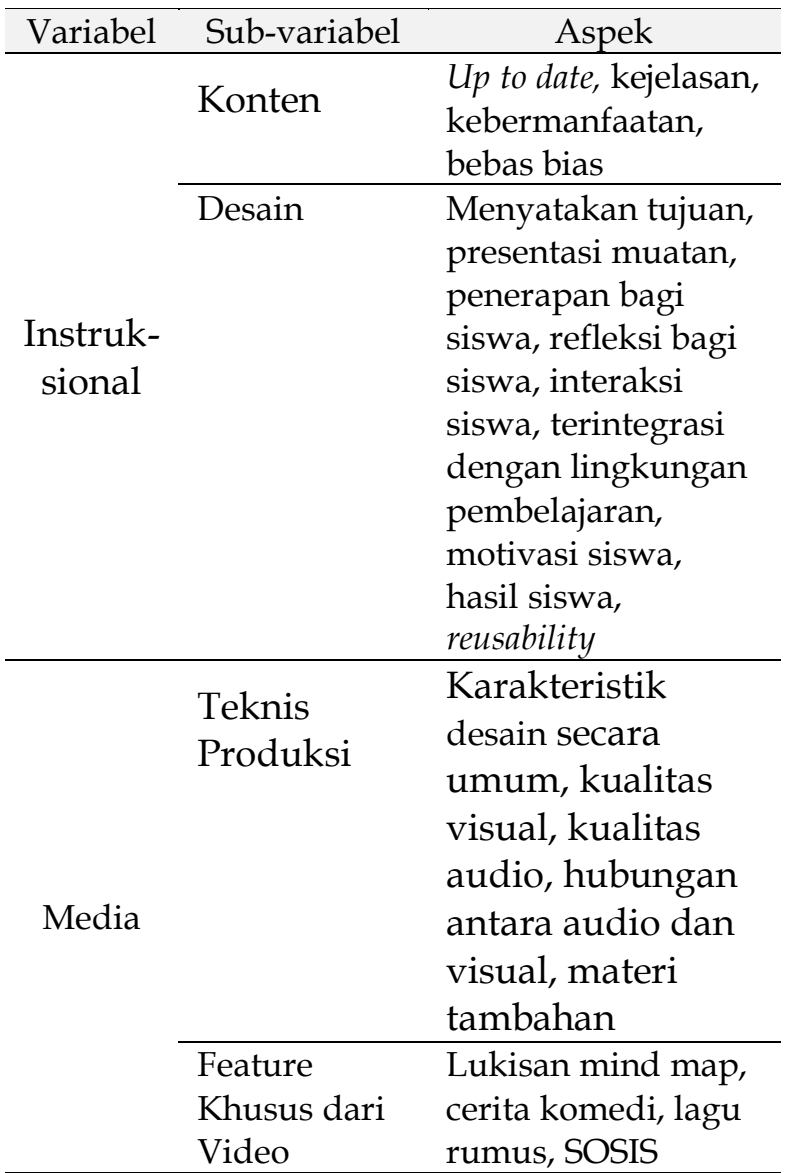

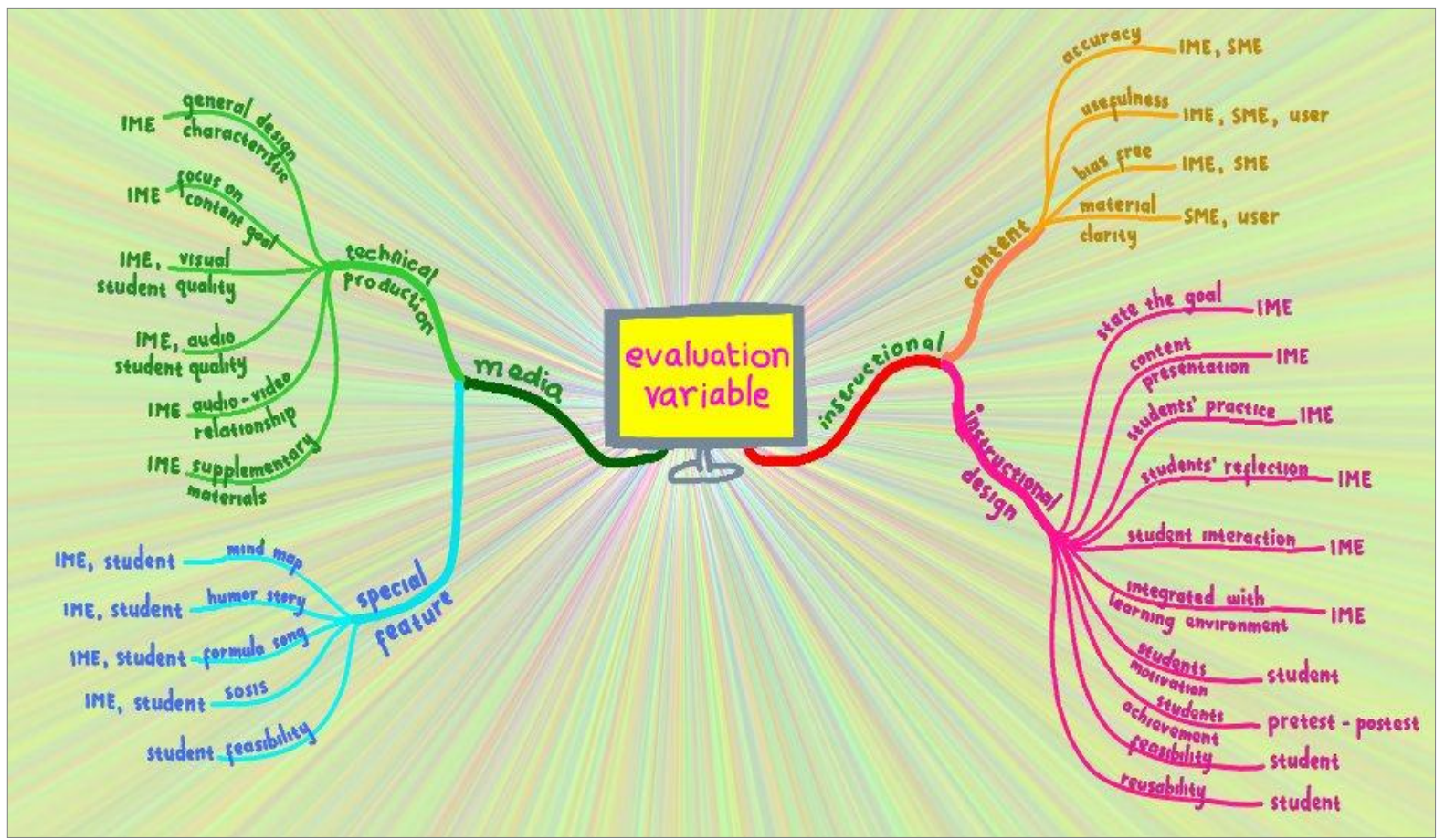

Gambar 1. Mind Map Variabel Evaluasi 
Kisi-kisi instrumen tersebut kemudian dituangkan dalam instrumen berupa kuisioner dan lembar interview. Instrumen didistribusikan kepada sumber-sumber data sesuai dengan kompetensinya masing-masing. Gambar 1 menunjukan peta pikiran dari variabel-variabel evaluasi yang terlibat dan bagaimana setiap aspek di dalamnya diberikan penilaian.

Terdapat dua variabel yang kemudian dibagi menjadi dua sub variabel, dimana masing-masing subvariabel memiliki aspek-aspek. Masing-masing aspek direview atau diberi penilaian oleh IME, SME, maupun siswa, tergantung dengan tipe aspek tertentu. SME mereview semua aspek dari konten. Kejelasan material yang direview oleh ahli adalah aspek kejelasan tujuan, kompetensi standar, petunjuk belajar, bahasa, dan info dari ilustrasi. Sedangkan IME mereview sebagian saja aspek dari kontek, sebagian aspek dari desain instruksional, seluruh aspek dari teknis produksi, dan sebagian aspek dari fitur khusus. Sementara itu data dikumpulkan dari siswa meliputi kejelasan material yang merupakan bagian dari subvariabel konten, sebagian aspek dalam desain intruksional seperti motivasi, prestasi, feasibilitas, dan pemakaian ulang (reusability). Data lain yang dikumpulkan dari siswa adalah kualitas audio visual yang meru-pakan aspek dari sub variable teknis produksi dan juga data mengenai semua aspek dalam fitur khusus. Data yang telah dikoleksi kemudian dikelompokkan dan dirangkai dalam analisis.

Teknik analisa data yang digunakan dalam studi deskriptif ini adalah analisis statistik deskriptif untuk data multimedia. Statistik yang digunakan untuk menilai kualitas multimedia adalah modus dari Skala Likert yang diperoleh melalui kuisioner, karena modus adalah nilai yang tepat untuk mewakili data ordinal (Mogey, 1998, p.21). Jika data dalam distribusi alami menghasilkan multimodal, maka median adalah indeks yang sesuai untuk digunakan (Bloomers, 1977, p.102). Sementara data analisis dalam bentuk nilai skor menggunakan mean yang mewakili sampel dan standar deviasi yang menunjukkan keragaman nilai (Bloomers, 1977).

\section{Hasil Penelitian dan Pembahasan}

Keenam ahli yang terlibat dalam review pada sub variabel materi, seri video Majoe Djaya memberikan penilaian akurasi yang baik bagi video Bilangan Bulat dan Logaritma dan akurasi yang cukup bagi video Badar dan Barung I. Kebermanfaatan video dikategorikan baik, sementara bebas bias dikategorikan lebih dari baik. Kejelasan video Bilangan Bulat adalah lebih dari cukup sementara kedua video yang lain adalah cukup. Gambar 2 menunjukkan index konten dari perspektif ahli.

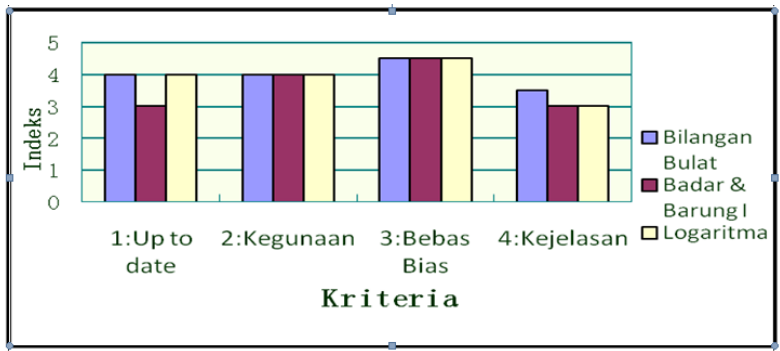

Gambar 2. Indeks Sub Variable Konten Menurut Review Ahli

Meski dikategorikan sebagai cukup, namun pada konteks init perlu dicatat sebagai kelemahan dari video, yaitu khususnya dalam hal kejelasan materi dan akurasi. Semenatara itu pada sub variabel desain instruksional para ahli melihat bahwa video dikategorikan sebagai baik maupun sangat baik dalam hal menyatakan tujuannya. Ketiga video juga dikategorikan baik dalam aspek presentasi konten, latihan, refleksi, kesesuaian dengan goal, dan terintegrasi pada lingkungan. Selain itu ketiga video dikategorikan cukup dalam hal interaksi. Indeks desain instruksional dalam persepektif ahli dapat dilihat pada gambar 3 di bawah ini. 


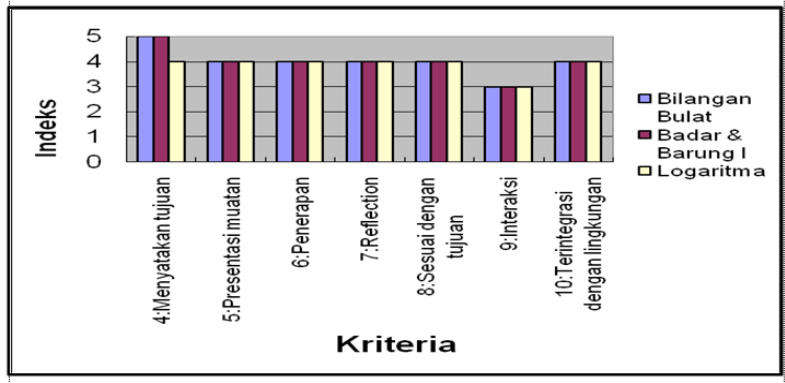

Gambar 3. Indeks Sub Variabel Desain Instruksional Menurut Review Ahli

Penilaian ahli dalam dalam hal interaksi ini menjadi temuan yang berlawanan dengan tujuan pengembang yang ingin menciptakan media yang meski berformat video namun dapat tetap interaktif. Observasi lapangan menunjukan bahwa para siswa terlibat aktif dalam kesibukan menyelesaikan latihan yang diberikan video. Dari hasil diskusi dengan ahli, ditemukan adanya kesalahan dalam penggunaan video pada sat review. Ahli umumnya tidak menyadari bahwa video harus dipause dan play seusai dengan petunjuk yang ada pada layar. Hal ini disebabkan oleh adanya persepsi bahwa format video adalah suatu media yang diputar dan ditonton dari awal hingga selesai dan audience hanya sebagai penonton pasif. Temuan ini merupakan dasar bagi perlunya materi tambahan atau suplemen yang tepat mengenai cara penggunaan video. Selanjutanya penilaian siswa sebagai pengguna dalam field test ditunjukan oleh gambar 4 sebagai berikut.

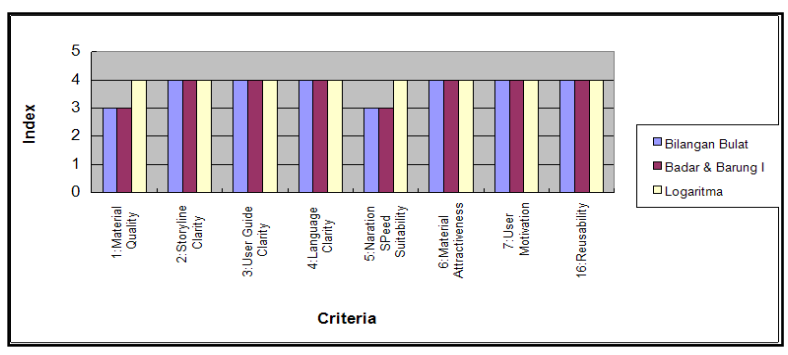

Gambar 4. Indeks Desain Instruksional dari Pengguna dalam Field Test

Kejelasan alur cerita, petunjuk penggunaan, kemenarikan materi, motivasi pengguna, dan reusability dikategorikan baik dari perspektif pengguna. Dalam aspek kualitas materi dan kecepatan narasi, video Bilangan Bulat dan Badar dan
Barung I dikategorikan cukup. Namun begitu Video Logaritma dikategorikan baik dalam kedua aspek tadi. Temuan ini menunjukan bahwa perbaikan kualitas materi dan penyesuaian kecepatan narasi pada video untuk siswa SD dan siswa untuk SMP perlu diperbaiki dan menyesuaikan dengan jenjang usia pengguna. Dari hasil one-to-one dan small group ditemukan bahwa siswa merasa kecepatan narasi terlalu cepat dan ada beberapa bagian yang meloncat-loncat sehingga siswa kesulitan memahami. Lebih lanjut grafik analisa perbandingan pretes dan postes pada Gambar 5, 6, dan 7 menunjukkan adanya tren yang mendukung kecenderungan ini.

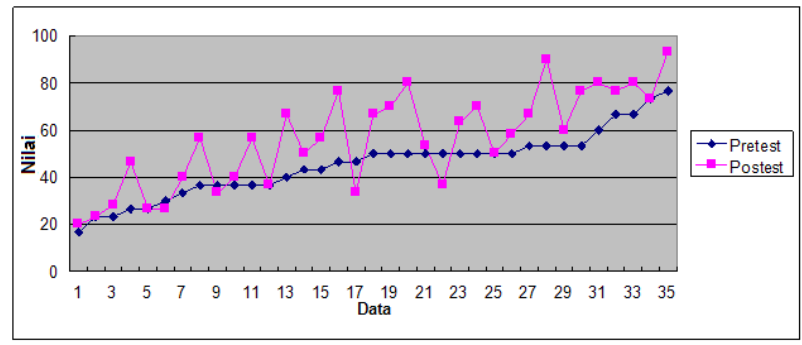

Gambar 5. Hubungan Pretest dan Postest Siswa Kelas 5 untuk Video Bilangan Bulat

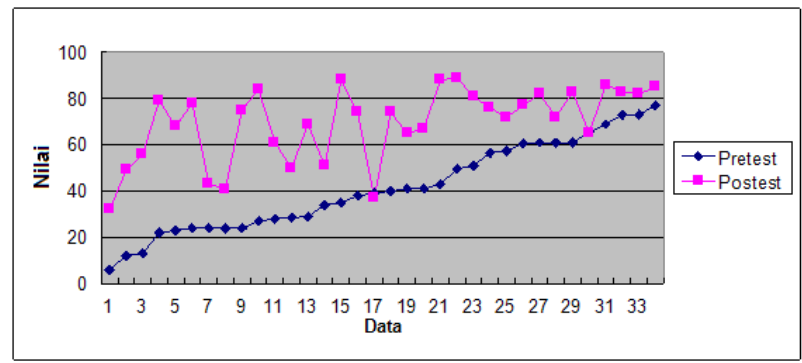

Gambar 6. Hubungan Pretest dan Postest Siswa Kelas 7 untuk Video Bilangan Bulat Badar \& Barung I

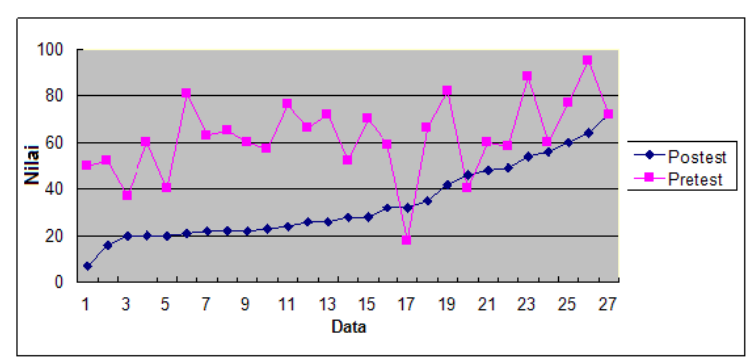

Gambar 7. Hubungan Pretest dan Postest Siswa Kelas 10 untuk Video Logaritma 
Ketiga gambar menujukan bahwa siswa yang memiliki hasil pretes rendah maupun tinggi dapat memiliki peningkatan nilai pada postes. Namun gambar 5 menunjukan selisih nilai peningkatan pretest-postest lebih kecil dari gambar 6 . Demikian pula selisih nilai peningkatan pretes-postes pada gambar 6 lebih kecil dari gambar 7. Dengan demikian video Logaritma menunjukan peningkatan nilai postes yang lebih baik dari pada kedua video lainnya.

Selanjutnya ditinjau dari aspek teknis produksi, secara umum ketiga video dikategorikan baik oleh ahli seperti ditunjukkan pada Gambar 8.

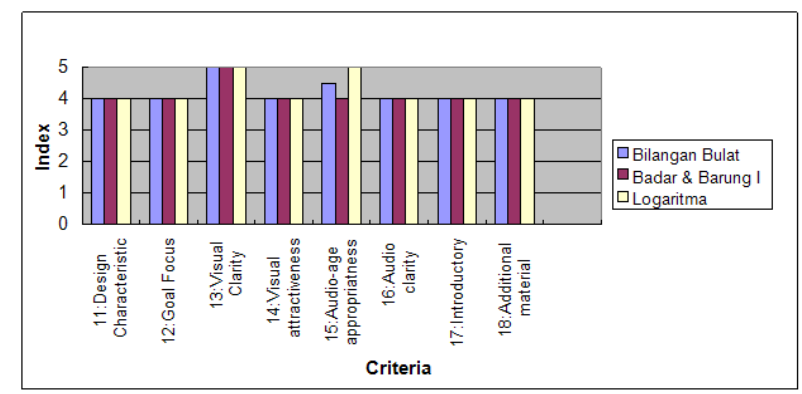

Gambar 8. Indeks Sub Variabel Teknis Produksi menurut review Ahli

Demikian juga dalam hal fitur spesial, ketiga seri video secara merata dikategorikan baik oleh para ahli seperti ditunjukan pada gambar 9 .

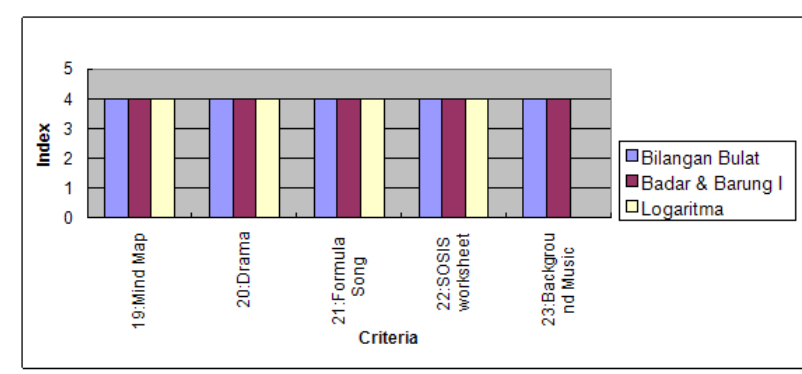

Gambar 9. Indeks Sub Variabel Fitur Khusus menurut Review Ahli

Namun pengguna memberikan penilaian yang lebih cukup variatif dalam variabel media secara keseluruhan. Pengguna mengkategorisasikan baik dalam aspek tampilan (look and feel), kemenarikan mind map, kemenarikan lembar kerja SOSIS, dan potensi distribusi. Sementara kejelasan audio, lagu rumus, dan back- ground musik dikategorikan cukup oleh pengguna. Video Bilangan Bulat dan Badar dan Barung I dikategorikan cukup dalam aspek kejelasan teks dan baik dalam kemenarikan drama. Sebaliknya video logaritma dikategorikan baik dalam aspek kejelasan teks dan dikategorikan cukup dalam kemenarikan drama. Indeks variabel media menurut pengguna tertera pada Gambar 10.

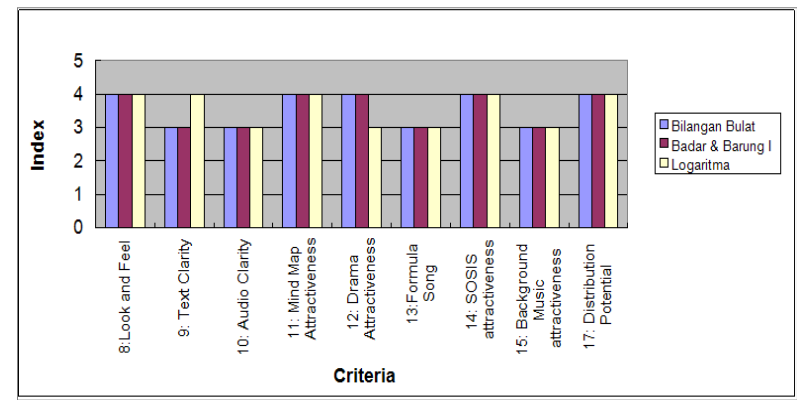

Gambar 10. Indeks Media dari Pengguna dalam Field Test

Tren yang kembali muncul pada gambar 10 adalah adanya kecenderungan kesamaan hasil penilaian pada video 1 dan video 2 yang diperuntukkan masingmasing bagi siswa SD dan siswa SMP. Sementara video 3 untuk siswa SMA memiliki karakteristik yang berbeda dari kedua video lainnya. Video 3 memiliki kejelasan teks yang lebih baik dari kedua video lainnya sehingga memudahkan siswa dalam mengikuti penjelasan materi SOSIS. Hal ini berkaitan dengan data pada gambar 4 mengenai kejelasan materi dan gambar 7 mengenai perolehan gain score yang lebih baik dari kedua video lainnya. Sebaliknya video 3 memiliki kemenarikan drama yang lebih rendah dari kedua video lainnya. Hal ini didukung oleh data kualitatif yang diberikan siswa berupa komentar umum setelah belajar dengan video pada bagian akhir instrumen. Siswa SD dan SMP memberikan komentar positif pada alur cerita dan bahkan beberapa siswa terlibat dalam mengidentifikasikan diri mereka dalam cerita monster dan superhero pada video bilangan bulat. Sementara siswa komentar siswa SMA pada umumnya menyebutkan bahwa alur cerita terlalu alay atau berlebihan. Temuan 
ini merupakan dasar untuk revisi yang penting bagi developer, yaitu bagaimana menemukan keseimbangan antara aspek kebenaran materi dan hiburan. Video 1 dan 2 cenderung menghibur namun kurang tepat dalam materi dan meningkatkan pemahaman siswa. Sebaliknya video 3 cenderung meningkatkan lebih baik dalam kualitas materi dan meningkatkan pemahaman siswa, namun aspek enterainment yang disajikan kurang tepat sasaran.

Selain itu terdapat tren bahwa aspek-aspek yang berhubungan dengan audio, seperti kejelasan audio, lagu rumus, dan musik latar, memperoleh modus 3 dalam hasil field test. Hasil observasi lapangan sehubungan dengan data ini menjelaskan bahwa penggunaan mini subwoofer speaker dalam ruangan kelas menghasilkan audio yang kurang maksimal dibandingkan pada subwoofer speaker untuk small group maupun speaker laptop untuk sessi one-to-one.

\section{Simpulan dan Saran}

Simpulan

Validitas instruksional dari video pembelajaran matematika Majoe Djaya dilihat dari tiga seri video, sejauh ini dapat dikatakan memiliki kualitas yang baik sebagaimana yang ditunjukan oleh skor modus 4 dari 5; (a) dilihat dari keakuratan konten, video dapat dikategorikan baik, sebagaimana ditunjukan dalam skor modus 4 dari skala 5; (b) dilihat dari kebermanfaatan, video dapat dikategorikan baik, sebagaimana ditunjukan dalam skor modus 4 dari skala 5; (c) dilihat dari kejelasan konten, video dapat dikategorikan cukup, sebagaimana ditunjukan dalam skor modus 3 dari skala 5; (d) dilihat dari strategi instruksional, video dapat dikategorikan baik, sebagaimana ditunjukan dalam skor modus 4 dari skala 5; (e) dilihat dari peningkatan motivasi siswa, video dapat dikategorikan baik, sebagaimana ditunjukkan dalam skor modus 4 dari skala 5; (f) Dilihat dari keefektifan outcome kognitif, video sejauh ini dapat meningkatkan out- come sebesar $44,36 \%$, sebagaimana ditujukan oleh gain score.

Validitas media pada video pembelajaran matematika Majoe Djaya jika dilihat dari tiga seri yang diteliti sejah ini dapat dikatakan memiliki kualitas yang baik sebagaimana ditunjukan oleh modus 4 dari 5 dalam Skala Likert; (a) dilihat dari karakteristik desain secara umum, video sejauh ini dapat dikategorikan sebagai baik yang ditunjukan oleh modus 4 dari skala 5; b) dilihat dari kualitas visual, video sejauh ini dapat dikatakan lebih dari baik ditunjukan oleh modus 4,5 dari skala 5; c) Dilihat dari kualitas audio, video sejauh ini dapat dikategorikan baik ditunjukan oleh modus 4 dari skala 5; d) dilihat dari kecukupan materi tambahan video dikategorikan baik ditunjukan oleh modus 4 dari skala 5; e) dilihat dari kemenarikan fitur spesial, video dikategorikan baik ditunjukkan oleh modus 4. f) dilihat dari reusability, video dikategorikan baik ditunjukan oleh modus 4 dari skala 5 .

Saran

Seri Video Majoe Djaya sesuai untuk penggunaan setelah beberapa revisi sebagaimana berikut ini: a) membagi video ke dalam potongan yang lebih pendek berisi sub bab dari materi; b) menyediakan material tambahan (suplemen) mengenai penjelasan dari peranan video dalam pembelajaran; c) menyediakan penjelasan tentang bagaimana menggunakan video baik bagi guru maupun siswa; d) menuliskan kompetensi dari video untuk meningkatkan kejelasan materi bagi siswa dan guru; e) memperbarui strategi pembelajaran sehingga tetap cocok dan seimbang antara aspek ketepatan materi dan aspek hiburan.

\section{Daftar Pustaka}

AECT Task Force On Definiton and Terminology. (1997). The definition of educational technology. Washington DC: Association For Educational Communication and Technology. 
Beaudin, B.P. (1993). Instructional video evaluation. Colorado: Colorado State University, Ft Collins.

Bloommers, P. J., \& Forsyth, R.A. (1977). Elementary statistical methods in psycholigicy and education. $2^{\text {nd }}$ ed. Boston: Houghton Mifflin Company.

Dick, W., Carey,L., \& Carey, J.O. (2009). The systematics design for instruction (7th ed). Boston : Pearson Education Inc.

Flagg, B.N. (1990). Formative evaluation for educational technologies. New Jersey: Lawrence Erlbaum Associates Publishers.

Gagne, R.M., Briggs, L.J., \& Wager, W.W. (1992). Principles of instructional design (4thed). Orlando: Harcourt Brace Jovanovich Publisher.

Mogey, N. (1998). So you want to use a Likert Scale?on J. Harvey (Ed), evaluation cookbook (p.21). [electronic version] Edinburgh: Learning Technology Dissemination Initiative.

Ogle, G.J. (2002). Towards A Formative Evaluation Tool. Virginia Polytechnic Institute.

Seels, B.B., \& Richey. R.C. (1994). Instructional Technology: The Definition and Domains of The Field, Association for Educational Communication and Technology, Washington, DC.

Smaldino, S.E., Lowther, D.L., \& Rusell, J.D. (2008). Instructional Technology and Media for Learning $9^{\text {th }}$ ed. New Jersey: Pearson Prentice Hall.

Weiss, C.H. (1972). Evaluation Research. New Jersey: Prentice Hall. Publication. Inc. 